\title{
BASAL COPPER EXCRETION IN WILSON'S DISEASE
}

\author{
BY \\ C. B. M. WARREN and P. M. G. BROUGHTON \\ From St. John's Hospital, Chelmsford
}

(RECEIVED FOR PUBLICATION NOVEMBER 6, 1963)

The clinical manifestations of Wilson's disease are believed to be due to the accumulation of toxic amounts of copper within the body. The primary aim of treatment is to remove these, usually by giving chelating agents that will combine with the copper and be excreted in the urine. The most effective of these therapeutic agents is penicillamine (Walshe, 1960), and clinical improvement follows in a high proportion of cases treated with this compound. When the more obvious clinical signs and symptoms have improved or disappeared it is difficult to judge the effectiveness of long-term treatment or to control dosage, and an objective method of assessing the degree of copper depletion is needed. This would be particularly valuable in those cases that are diagnosed from the biochemical findings and the family history, and may be treated with chelating agents before the typical signs have developed.

Warren and Broughton (1962) described a case of Wilson's disease that had been successfully treated with D-penicillamine for four years, and they found that the best biochemical index of long-term response to treatment was the basal copper excretion measured on urines collected after penicillamine had been stopped for several days. This paper describes some further basal copper excretion results on this case, and on five others with Wilson's disease, before and after treatment with D-penicillamine.

\section{Methods}

At least two consecutive 24-hour urine collections were made into polythene bottles before penicillamine treatment was started, and these were analysed for copper by a modification of the method of Earl (1954), after ashing an aliquot of the urine with sulphuric and perchloric acids. The test was repeated at intervals after penicillamine therapy, the drug having been stopped for at least three days before and during each period of urine collection.

The basal copper excretion was defined as the 24-hour output in the urine, measured on at least two consecutive specimens, after all cupruretic therapy had been discontinued for at least three days.

\section{Results and Discussion}

The daily copper excretion of patients with Wilson's disease varies considerably, and on successive days may differ by as much as $100 \%$. This may be due to fluctuations in the amount of copper in the diet, but will also depend on the intake of amino acids (Matthews, Milne and Bell, 1952) and of protein (Bearn and Kunkel, 1954). Copper excretion is also likely to be influenced by oestrogenic (German and Bearn, 1961) and adrenocortical activity (Bearn and Kunkel, 1954) and by renal function. But the analysis of duplicate specimens, at regular intervals, as in the cases reported here, reduces the effect of the variables, and enables the trend of the results to be clearly seen (Fig. 1).

The basal copper excretion of all six cases reported here showed a significant fall after penicillamine treatment (Table 1); and in those cases with symptoms, there has been a corresponding clinical improvement. A number of published reports

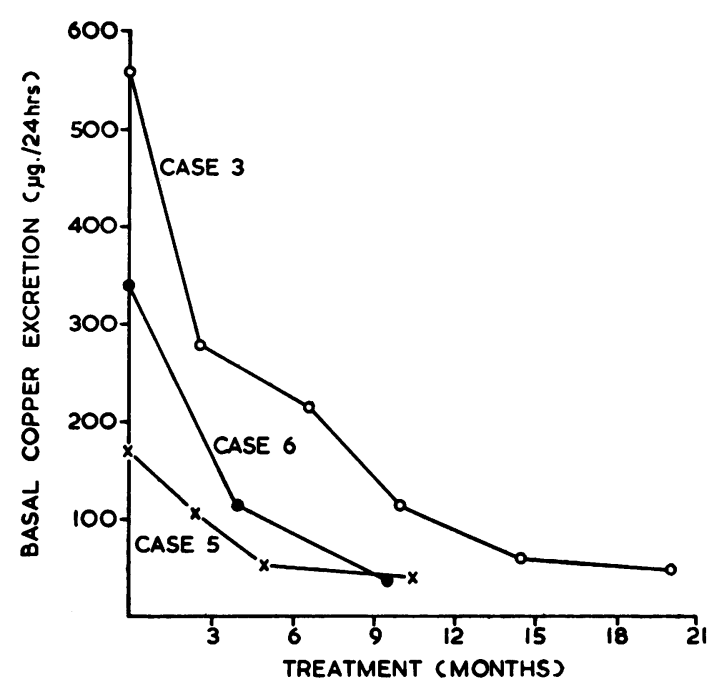

FIGURE-Changes in basal copper excretion during treatment. 
TABLE 1

BASAL COPPER EXCRETION RESULTS

\begin{tabular}{|c|c|c|c|c|c|}
\hline \multirow{2}{*}{ Case No. } & \multirow{2}{*}{ Age (yr.) } & \multirow{2}{*}{ Presentation } & \multirow{2}{*}{$\begin{array}{c}\text { Duration of } \\
\text { Penicillamine } \\
\text { Treatment }\end{array}$} & \multicolumn{2}{|c|}{$\begin{array}{l}\text { Basal Copper Excretion } \\
(\mu \mathrm{g} . / 24 \mathrm{hr} .)\end{array}$} \\
\hline & & & & $\begin{array}{c}\text { Before } \\
\text { Treatment }\end{array}$ & $\begin{array}{c}\text { After } \\
\text { Treatment }\end{array}$ \\
\hline $1^{*}$ & $\left\{\begin{array}{r}7 \\
11 \\
12 \\
18\end{array}\right.$ & $\begin{array}{l}\text { Jaundice } \\
\text { Neurological symptoms } \\
\text { Diagnosis; penicillamine started } \\
\text { Well }\end{array}$ & $5 \frac{1}{2}$ years & 290 & 50 \\
\hline $2 *$ & $\left\{\begin{array}{r}-6 \\
9 \\
12\end{array}\right.$ & $\begin{array}{l}\text { Brother of Case } 1 \\
\text { Asymptomatic } \\
\text { Liver biopsy: cirrhosis }+\mathrm{Cu} \text {; penicillamine started } \\
\text { Well }\end{array}$ & $2 \frac{1}{2}$ years & 470 & 80 \\
\hline 3 & $\left\{\begin{array}{l}12 \\
14 \\
18 \\
21 \\
22 \\
24\end{array}\right.$ & $\begin{array}{l}\text { Jaundice } \\
\text { Neurological symptoms } \\
\text { Diagnosis. BAL treatment } \\
\text { Relapse } \\
\text { Penicillamine started } \\
\text { Well }\end{array}$ & 2 years & 560 & 50 \\
\hline 4 & $\left\{\begin{array}{c}\overline{8} \\
9\end{array}\right.$ & $\begin{array}{l}\text { Elder sister died aged } 11 \mathrm{yr} \text {. with Wilson's disease } \\
\text { Asymptomatic; biochemical diagnosis } \\
\text { Penicillamine started } \\
\text { Well }\end{array}$ & 17 months & 200 & 53 \\
\hline 5 & $\left\{\begin{array}{l}7 \\
11 \frac{1}{2} \\
12\end{array}\right.$ & $\begin{array}{l}\text { Hepatitis } \\
\text { Liver failure; diagnosis; penicillamine started } \\
\text { Well }\end{array}$ & 10 months & 170 & 40 \\
\hline 6 & $\left\{\begin{array}{l}-8 \\
9\end{array}\right.$ & $\begin{array}{l}\text { Younger sister of Case } 5 \\
\text { Asymptomatic; biochemical diagnosis } \\
\text { Penicillamine started } \\
\text { Well }\end{array}$ & 9 months & 340 & 35 \\
\hline
\end{tabular}

* Cases 1 and 2 were described more fully by Warren and Broughton (1962).

include similar figures (Table 2), although previous authors do not seem to have commented upon these changes in copper excretion.

In an earlier report (Warren and Broughton, 1962), it was found that remission of the symptoms in Case 1 occurred by the time the basal copper excretion had fallen to approximately $100 \mu \mathrm{g}$. $/ 24 \mathrm{hr}$.; when treatment became intermittent, symptoms began to reappear when the excretion increased much above $100 \mu \mathrm{g} . / 24 \mathrm{hr}$. We have therefore aimed at reducing the basal copper excretion to below this figure. The

TABLE 2

SOME BASAL COPPER EXCRETION RESULTS REPORTED PREVIOUSLY

\begin{tabular}{|c|c|c|c|}
\hline \multirow{2}{*}{ Reference } & \multirow{2}{*}{$\begin{array}{c}\text { Duration of } \\
\text { Penicillamine } \\
\text { Treatment }\end{array}$} & \multicolumn{2}{|c|}{$\begin{array}{c}\text { Basal Copper } \\
\text { Excretion } \\
(\mu \mathrm{g} . / 24 \mathrm{hr} .)\end{array}$} \\
\hline & & $\begin{array}{c}\text { Before } \\
\text { Treatment }\end{array}$ & $\begin{array}{c}\text { After } \\
\text { Treatment }\end{array}$ \\
\hline $\begin{array}{l}\text { Boulding (1961) } \\
\text { Garland and Sumner (1961) } \\
\text { Lange (1961) } \\
\text { Sherlock (1961) } \\
\text { Walshe (1961) }\end{array}$ & $\begin{array}{l}1 \frac{1}{2} \text { years } \\
2 \text { years } \\
3 \frac{1}{2} \text { years } \\
9 \text { months } \\
2-3 \text { years } \\
1 \text { year }\end{array}$ & $\begin{array}{c}257 \\
590 \\
1,061 \\
409 \\
529 \\
309 \\
360 \\
0 \cdot 5^{*}\end{array}$ & $\begin{array}{c}\text { less than } 80 \\
250 \\
202 \\
200 \\
77 \\
71 \\
43 \\
0 \cdot 15^{*}\end{array}$ \\
\hline
\end{tabular}

* $\mu g$. per minute time taken to bring it down to this relatively safe level will presumably depend upon the size of the initial copper pool and the dosage of penicillamine used. The speed of this biochemical remission in these six cases has varied from six months (Case 1 of Warren and Broughton, 1962) to two years (Case 2), and did not appear to be related either to the initial severity of the disease or to the basal copper excretion before treatment.

When there is no renal disease the basal copper excretion is probably an index of the total body copper pool. The copper content of the liver is presumably another such measure, and Sherlock (1961) and Sternlieb and Scheinberg (1963) have found that this is reduced following penicillamine treatment, with accompanying clinical improvement. The amount of copper in the body is probably a relative, and not an absolute, measure of the severity of the disease, and many other factors, including the variable sensitivity of organs to copper, will determine when clinical signs and symptoms appear.

Because of the wide range of clinical effects in Wilson's disease it is difficult to find an objective measure, applicable to all cases, which records their progress. The basal copper excretion appears to be promising in this respect, and the test is simpler than regular liver copper analysis advocated by Sternlieb 
and Scheinberg (1963). It remains to be seen whether this index can be used to control the longterm dosage of penicillamine in patients who have shown a good initial clinical improvement.

It is noteworthy that three of these six cases were diagnosed when they were asymptomatic and had no Kayser Fleischer rings. This emphasizes the importance of full investigation of all sibs of patients with Wilson's disease.

\section{Summary}

The basal copper excretion of six cases of Wilson's disease has been estimated before and after treatment with penicillamine. In all cases a striking fall was demonstrated after several months.

These results suggest that this test may be a relatively simple method of assessing the extent to which the body has been depleted of copper and may thus be a useful guide to the choice of long-term maintenance dosage of penicillamine.

The authors wish to thank Professor J. N. Cumings, Dr. R. H. Dobbs, Dr. I. G. Wickes and Mr. M. C. Wilkinson for permission to study their patients; and Dr. W. J. Dangerfield and Dr. J. M. Walshe for two of the results quoted for Cases 4 and 5 respectively.

\section{REFERENCES}

Bearn, A. G. and Kunkel, H. G. (1954). Abnormalities of copper metabolism in Wilson's disease and their relationship to the aminoaciduria. J. clin. Invest., 33, 400.

Boulding, J. E. (1961). Treatment of Wilson's disease with D-penicillamine. In Wilson's Disease. Some Current Concepts, ed. J. M. Walshe and J. N. Cumings, p. 224. Blackwell Scientific Publications, Oxford.

Earl, C. J. (1954). Screening test for excessive urinary copper. Lancet, 1, 234.

Garland, H. and Sumner, D. (1961). The treatment of Wilson's disease with penicillamine. In Wilson's Disease. Some Current Concepts, ed. J. M. Walshe and J. N. Cumings, p. 227. Blackwell Scientific Publications, Oxford.

German, J. L. and Bearn, A. G. (1961). Effect of oestrogens on copper metabolism in Wilson's disease. J. clin. Invest., 40, 445.

Lange, J. (1961). Experiences in long-term treatment of Wilson's disease with penicillamine. In Wilson's Disease. Some Current Concepts, ed. J. M. Walshe and J. N. Cumings, p. 267. Blackwell Scientific Publications, Oxford.

Matthews, W. B., Milne, M. D. and Bell, M. (1952). The metabolic disorder in hepatolenticular degeneration. Quart. J. Med., 21, 425.

Sherlock, S. (1961). Hepatic aspects of Wilson's disease. In Wilson's Disease. Some Current Concepts, ed. J. M. Walshe and J. N. Cumings, p. 182. Blackwell Scientific Publications, Oxford.

Sternlieb, I. and Scheinberg, I. H. (1963). The diagnosis of Wilson's disease in asymptomatic patients. J. Amer. med. Ass., 183, 747.

Walshe, J. M. (1960). Treatment of Wilson's disease with penicillamine. Lancet, $1,188$.

- (1961). In Discussion. In Wilson's Disease. Some Current Concepts, ed. J. M. Walshe and J. N. Cumings, p. 243. Blackwell Scientific Publications, Oxford.

Warren, C. B. M. and Broughton, P. M. G. (1962). Wilson's disease. Arch. Dis. Childh., 37, 242. 